\title{
直進形クレーンにおける吊り荷の横摇れ抑制制御
}

\author{
橋 本 幸 男* 土谷 武士** 杉 岡一 郎* 松 田 敏 彦*
}

\section{Transversal Load-Swing Suppression Control of Travelling Crane}

\author{
Yukio HASHIMOTO Takeshi TSUCHIYA Ichiro SUGIOKA Toshihiko MATSUDA
}

In travelling crane systems, the load-swing sometimes has an oscillation component perpendicular to a travelling direction by accidental disturbances. This paper analyzes the dynamics of the load swing with the rope length as another control channel to the crane system and proposes a control strategy both to suppress the load swing and to control the trolley position. In the control, the rope length is variated to move the load upwards and downwards following to a sinusoidal function so that the swing direction of the load rotates. At the same time, the trolley is controlled to eliminate the oscillation component of the load growing in its travelling direction and to approach to a desired position of the trolley. The control is evaluated by numerical experiments and proved to be effective.

Key Words : Oscillation control, Control of crane, Travelling crane, Control of nonlinear system

\section{1.はじめに}

クレーンの運転に制御を導入して荷役作業の安全と 効率化を図る研究が行われてきた。近年は, 計算機統 合生産システムにおける部材や製品の 3 次元的な搬送 手段としてクレーンが見直され，その制御が改めて関 心を呼んでいる11. 直進型のクレーンだけに限って も，これまでに，吊り荷に残留振れを残さないように 高速に搬送する方式 ${ }^{2), 3)}$ 荷の巻き上げ・巻き下げも考 慮に入れて荷を高速に搬送する方式). 荷の巻き上 げ・巻き下げだけで振れを止める制御方式 ${ }^{5)}$ 。また搬 送ごとのパラメー夕の大きな変化に積極的に対処する ものとして荷が静止している状態から搬送を開始し, 途中でそれまでの運動を折り返すことによってパラメ 一夕に不感な制御を実現する方式6)，適応制御を用い る方式7),8), クレーンの力学的構造を利用する方式9) 等, 数多くの提案がなされてきた.

直進型クレーンに関する荷摇れ防止制御の従来の研

原稿受付 1992 年 12 月 10 日

*室蘭工業大学

**北海道大学工学部
究では, トロリー(あるいはホイスト)の移動方向のみ の荷摇れが議論の対象とされてきた。しかし現実の搬 送作業を想定すると, 巻き上げ時の横引きのせいや, 屋外での搬送中に横から突風を受けるなどして，トロ リーの移動方向と直交する方向に荷の摇れが残る場合 がある. 天井クレーンのようにトロリーが 2 次元的に 動く構造のクレーンでは従来の振れ止め制御を各軸独 立に実行することによって容易にこの振れを止めるこ とができると予想されるが，テルハクレーンのように ホイストが一次元的にしか動けない構造のクレーン や，トロリーが主として一次元的に動いて作業を行う アンローダあるいはコンテナクレーンの場合では, こ の横方向に残る摇れを止めることが問題となる．本論 文では，一次元的にしか動けないクレーンでも巻き上 げ機構が標準的に装備されていることを利用して, 横 方向の摇れも抑えながら荷を目標位置まで搬送するク レーンの制御について議論する.

まず最初に, 直進型クレーンの荷の摇れを 3 次元空 間内における運動として定式化し，巻き上げ機構も制 御の入力チャンネルと考えた場合のクレーンの力学的 な構造を解析する，その結果，トロリーから下を見て 
楕円を描くように荷が摇れているときに，横方向の荷 の振れを巻き上げ機構を使って減衰させたなら，トロ リーの移動方向の振れが増大してしまうこと, また,

トロリーの運動は横方向の振れには影響を与えないこ とを明らかにする.クレーン・システムは運動の自由 度の数より入力の数が少ない，いわゆる「不足入力系」 として知られているが巻き上げ機を入力とするときの 吊り荷の運動は, 線形化近似システムを導けない形の 非線形な微分方程式に従っていることもここで明らか にされる，つぎに，以上の結果を踏まえ，楕円を描く ように荷の振れが生じたときには荷の巻き上げと巻き 下げを周期的に行いながら横方向の摇れをトロリーの 移動方向へ回転させ，その摇れをトロリーの移動で止 めながらトロリーの位置の制御も同時に実現する制御 方策を提案する.

\section{2. 運動方程式の導出}

現実を反映した直進形クレーンの運動方程式は後述 するものとし, ここでは荷の振動運動の力学的な特徵 を探るために，ロープの長さとトロリーの移動加速度 が外部から自由に変えられるという理想的な場合の吊 り荷の従うべき運動方程式を示す。八ミルトンの原理 を用いて運動方程式を導出するのが簡便であるので, ここでも八ミルトンの原理に従う。

いま，クレーン・システムに対して座標を Fig.1の ように定め, 以下に示す記号を定義する.

$\chi:$ トロリーの $X$ 座標

$x: \mathrm{X}$ 軸方向の荷の重心の振れ幅

$y: \mathrm{Y}$ 軸方向の荷の重心の振れ幅

$z: Z$ 軸方向の荷の重心の位置

$l:$ トロリーから荷の重心までの距離すなわち,

等価ロープ長

$M:$ トロリーの質量

$m:$ 吊り荷の質量

$g:$ 重力加速度

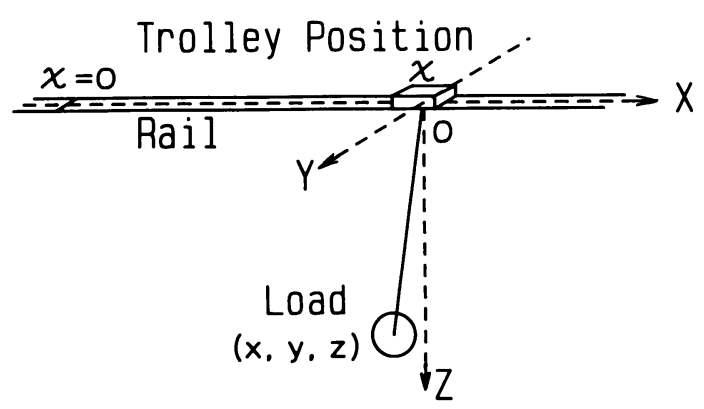

Fig. 1 Crane system and its coordinates
このとき, 系のラグランジアンは， $T, V$ をそれぞれ運 動エネルギ, 重力によるポテンシャルエネルギとすると

$$
\begin{gathered}
L=T-V \\
T=\frac{1}{2} m\left[(\dot{x}+\dot{\chi})^{2}+(\dot{y})^{2}+(\dot{z})^{2}\right] \\
V=-m g z
\end{gathered}
$$

のように計算される，ただし，ここに現れた変数はす べてが独立ではなく, 変数間には

$$
x^{2}+y^{2}+z^{2}=l^{2}
$$

の関係が常に成立していなければならない。したがっ て, 系の運動方程式を定めるには, 式 (4)を拘束条件 とみなした次の汎関数を停留させる条件を求めればよ (10).

$$
\begin{array}{r}
J=\int_{t_{1}}^{t_{2}}\left[L+\lambda\left(x^{2}+y^{2}+z^{2}-l^{2}\right)\right] d t \\
\lambda \text { はラグランジュの未定関数 }
\end{array}
$$

付録 A に示すように，式（5)の第一変分を 0 にする 条件から, 吊り荷が従うべき運動方程式は以下のよう に定められる.

$$
\begin{gathered}
\ddot{x}=-\frac{x}{l^{2}} f-\ddot{\chi} \\
\ddot{y}=-\frac{y}{l^{2}} f \\
\ddot{z}=g-\frac{z}{l^{2}} f
\end{gathered}
$$

ただし，

$$
f=(\dot{x})^{2}+(\dot{y})^{2}+(\dot{z})^{2}+z g-(i)^{2}-l \ddot{l}-x \ddot{x}
$$

で, $l, i, \ddot{l}$ と $\ddot{\chi}$ が外部からこの振動系へ与えること のできる入力とみなされる.

式 (6)，(7)，(8)を幾何学的な観点から考察してみ ると, $m f / l$ がロープの張力を表していることが分か るからロープが弛まない条件が求まり, 次式となる.

$$
(\dot{x})^{2}+(\dot{y})^{2}+(\dot{z})^{2}+z g-(\dot{l})^{2}-l \ddot{l}-x \ddot{x} \geqq 0
$$

\section{3. 運動方程式の特徵}

制御を考える準備として, 前章で求めた運動方程式 の構造が分かる幾つかの事実を示す.

まず最初に，巻き上げ・巻き下げ機構を使って荷を 上下に動かしたときの運動を解析する．トロリーに関 しては, 静止しているかあるいは等速運動を行ってい るものとし

$$
\ddot{\chi}=0
$$

の条件が成立しているものと仮定する.

いま，上記の条件の下で，トロリーから下を見て荷 が楕円を描くように摇れている場合を考える.このよ うなとき, 式(7)に $x$ を掛けたものから式(6)に $y$ 
を掛けたものを辺々減じると

$$
x \ddot{y}-y \ddot{x}=0
$$

の関係を得るが, この式(10)の左辺は $Z$ 軸回りの角 運動量

$$
J_{z}=x \dot{y}-y \dot{x}
$$

を時間微分したものになっている(正しくは角運動量 を荷の質量で割ったものであるが，本質は失われない ので以降ではこれを角運動量と呼ぶ)。この結果は「ど のように荷の巻き上げ・巻き下げの制御を行っても荷 の摇れに伴う角運動量の值を変えることができない」 という事実を表しており，巻き上げ機構を使うだけで はどのように制御したとしても，棈円を描くように摇 れている荷を静止させることはできないということを 示している.

次に, 式 ( 9 )の条件の下に X 軸回りの角運動量の 時間的な変化を求めると次式を得る.

$$
\begin{aligned}
\left(\dot{J}_{x}\right)^{2} & =y^{2} g^{2} \\
& =\left(l^{2}-x^{2}-z^{2}\right) g^{2}
\end{aligned}
$$

この場合にはロープの長さがパラメータとして残るの で巻き上げ機構を使うとY 軸方向の摇れの制御が実 現できる可能性が出てくる．実際 $\mathrm{Y}$ 軸方向に振れの 角度が $\theta(t)$ で摇れている場合，ロープの長さ $l$ が $d l$ だけ変わるときの吊り荷に与えられる仕事は，ロープ の張力が重力によるものと遠心力によるものからなる ことを考慮すると，次のように求められる.

$$
\begin{aligned}
d W & =-\left(m g \cos \theta+m l \dot{\theta}^{2}\right) d l \\
& \fallingdotseq-m g d l+m\left(\frac{1}{2} g \theta^{2}-l \dot{\theta}^{2}\right) d l
\end{aligned}
$$

ただし $\theta$ は鉛直軸 $(Z$ 軸) とロープのなす角である.

上式最右辺の第一項は吊り荷が $d l$ だけ上下に移動 することによる重力のポテンシャルエネルギの変化を 表し, 第二項目が単振動の力学的エネルギの増減を決 めていると解釈できるから，吊り荷の Y 方向の振れ の状態を観測しながら

$$
\begin{aligned}
& g \theta^{2} \geqq 2 l \dot{\theta}^{2} \text { のとき } d l<0 \\
& g \theta^{2}<2 l \dot{\theta}^{2} \text { のとき } d l>0
\end{aligned}
$$

のように荷の巻き上げと巻き下げを行えば，荷の摇れ を隇衰させることが可能となる。しかし，先に示した ように $Z$ 軸回りの角運動量が保存されなければなら ないので，特定の方向の振動が抑制されたとしても， それと直交する方向の摇れが増大する結果となる，従 来から巻き上げ機構を使って荷の振れを止める制 御5),11)も検討されてきたがこのような事実はこれまで 指摘されていなかったように思われる。

最後に，ロープの長さを一定值に固定し，トロリー
のみを動かすときの荷の運動を検討してみる。このと きには，トロリーの移動方向，すなわちX軸方向の 振れの成分が影響を受けるのは式 (6) から直ちに分か る. 一方 Y 軸方向の振れに対しては, 式 $(7)$ から分 かるように, トロリーの運動は

$$
-\frac{x y}{l^{2}} \ddot{\chi}
$$

という項を介してしか荷の摇れに影響を与えない。通 常荷の摇れは小さいと考えてよいし，ロープの長さも 長いからこの項の寄与は無視できる。すなわち，Y 軸方向の摇れはトロリーの移動だけでは制御できな い。このことは直進形のクレーンにおいて，一度横摇 れが発生するとトロリーを移動させてもその摇れを止 められないという経験的な事実とも合致している.

\section{4. 吊り荷の振れ止め制御}

前章の解析結果によれば，特定の方向にのみ荷の摇 れが生じた場合，巻き上げ機構を使うと摇れを抑えら れるが，楕円を描くように荷が摇れている場合には摇 れが抑えられるにつれ制御を加えない方向の振動が増 大することが分かった，一方，トロリーをどのように 移動させても $\mathrm{Y}$ 軸方向の荷の摇れには影響を与えな

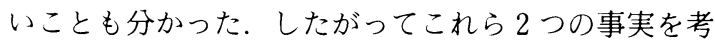
慮すると，楕円を描くように荷が振れてしまった場合 には，まず最初に巻き上げ機構を使って Y 軸方向の 振れを抑制しつつX軸方向の振れを増大させ，それ をトロリーの移動で減衰させるという制御方策をとる のが妥当と考えられる。本章ではこの制御を実現する 具体的な方法について検討する。

クレーンの制御でよく仮定するように，ここでも吊 り荷の摇れは小さいものと考えるが，式(6)，（7)で 与えられる非線形な運動方程式は, 安定平衡点の周り で線形化しても，ロープの長さを入力として含む形の 線形状態方程式は得ら机ない。このため, 以降では以 下のように 2 次の微小量を無視した近似式を使って議 論を進める。

$$
\begin{gathered}
\ddot{x}=-\frac{x}{l}(g-\ddot{l})-\ddot{x} \\
\ddot{y}=-\frac{y}{l}(g-\ddot{l})
\end{gathered}
$$

また，制御に必要な状態量はすべてが観測可能である として議論を進める.

\section{$4.1 \mathrm{Y}$ 軸方向の振れ止め制御}

巻き上げ機構を利用した荷の振れ止め制御に関して はある評価指標の下に最適制御問題を定式化し, 
Bang Bang 制御解を求めてこれを開ループで実行す る方法到かこれを簡略化した方法11)が知られてい る. しかし現実には急激に荷の上げ下げを行うと，口 ープの弾性が無視できないことや振れの角度検出の限 界などのために数值実験で予想されるほどの結果は得 られないようである，本論文では，巻き上げや巻き下 げを急激に行うことは荷の飛び跳ねを招くので好まし くないという観点から, 荷の上げ下げは滑らかな関数 に従わせるという方針をとる.

いま, 等価ロープ長が $l_{0}$ で荷が楕円を描いていた とする、Y 軸方向の摇れが $\mathrm{X}$ 軸を $\mathrm{Y}$ の正の向きによ ぎる時点を時間の原点にとり, 荷の $\mathrm{Y}$ 軸方向の振動 を表そう。前章の考察によれば，トロリーがどのよう に運動しようともY方向の振れは影響を受けないと 考えてよかったので，この振動は次のような式で書か れる。

$$
\begin{aligned}
& y=A_{y} \sin \left(\omega_{0} t\right) \\
& A_{y}>0, \omega_{0}^{2}=g / l_{0}
\end{aligned}
$$

ここで, 巻き上げ機構を使い, ロープの長さを次式に 従って変化させたとする.

$$
\begin{gathered}
l=l_{0}+a \sin \left(2 \omega_{0} t\right) \\
0<a \ll l_{0}
\end{gathered}
$$

ロープの長さの変化はロープ長に対して十分小さいも のと仮定しているから，式(16)に従って荷を上下に動 かしても摇れの周波数はほとんど変わらないと考えて よいし，また式(15)が式(14)の近似解となることも予 想できる.

いま，Y 方向での荷の振れを表す尺度として次の 量を選ぶ.

$$
E=\frac{1}{2}(\dot{y})^{2}+\frac{1}{2} \frac{g}{l_{0}} y^{2}
$$

振れの振幅值が準静的に変化するものと仮定し, 式 （14）と式(15)，(16)を考慮に入れて式(17)の時間微分 を調べてみると次式が示される(付録 B 参照).

$$
\dot{E}=-\frac{3 a A_{v}{ }^{2} \omega_{0}{ }^{3} \sin ^{2}\left(2 \omega_{0} t\right)}{2\left[l_{0}+a \sin \left(2 \omega_{0} t\right)\right]} \leqq 0
$$

等号の成立は $A_{y}=0$ のとき

このことから, 式(17)は近似的なリアプノフ関数にな っており，式(16)で与えられる簡単な開ループ制御だ けでも Y 方向の荷の振れの減衰制御が期待できるの が分かる.

ブランコの場合, 摇れの周期の半分の周期で摇れと 同期して漕ぐと増大することが知られている ${ }^{122}$ が, 式(16)の制御はこれと反対のことを行っているにすぎ ない. 式(16)の制御の制振効果の詳細は後の章で数值
実験を通して明らかにする。

\section{$4.2 \mathrm{X}$ 軸方向の振動制御と位置制御}

$\mathrm{X}$ 軸方向に対しては, 荷の振れを止めるだけでな く,トロリーの位置の制御も同時に考える.ただし, 標準的なクレーンの場合, トロリーを駆動する電動機 のドライバには速度指令を与える入力チャンネルが装 備されていることを考慮して, ここではトロリーを動 かす速度指令則を次式で与えることを提案する。

$$
\begin{aligned}
\dot{\chi}= & k_{d} x+k_{d T}\left(\chi-\chi_{0}\right) \\
& +\int_{0}^{t}\left[k_{0} x(\tau)+k_{\rho T}\left\{\chi(\tau)-\chi_{0}\right\}\right] d \tau
\end{aligned}
$$

ただし，

$k_{d}, k_{d T}, k_{0}, k_{\rho}, k_{0}:$ 制御ゲイン (定数)

$$
\chi_{0}: \text { トロリーの終着目標位置 }
$$

とする.

以下においては, 荷の振動やトロリーの移動という 機械系の動きに比べ電動機の速度制御系の応答が高速 であると仮定して, 式(19)の制御則がここでの制御目 的を達成するフィードバック制御則になっていること を示す。

式(19)を式(13)に代入することにより, 次式を得 る.

$$
\begin{gathered}
\ddot{x}=-\frac{x}{l}(g-\ddot{l})-k_{d} \dot{x}-k_{\rho} x \\
-k_{d T} \dot{\chi}-k_{\rho T}\left(\chi-\chi_{0}\right) \\
\text { ところで } \\
\mathrm{x}=\left(x_{1}, x_{2}, x_{3}, x_{4}\right)^{T}=\left(\chi-\chi_{0}, \dot{\chi}, x, \dot{x}\right)^{T}
\end{gathered}
$$

なる状態変数を導入すると, 式(19), (20) は状態方程 式の形に書き直すことができ, 以下のように変形でき る.

$$
\begin{aligned}
& \dot{\mathrm{x}}=\left[\begin{array}{cccc}
0 & 1 & 0 & 0 \\
-k_{\rho T}-k_{d T} & -k_{\rho} & -k_{d} \\
0 & 0 & 0 & 1 \\
-k_{\rho T}-k_{d T}-k_{\rho}-(g-\ddot{l}) / l-k_{d}
\end{array}\right] \mathrm{x} \\
& =\left[\begin{array}{cccc}
0 & 1 & 0 & 0 \\
-k_{\rho T}-k_{d T} & -k_{\rho} & -k_{d} \\
0 & 0 & 0 & 1 \\
-k_{\rho T}-k_{d T} & -k_{\rho}-g / l_{0}-k_{d}
\end{array}\right] \mathrm{x} \\
& +\left[\begin{array}{c}
0 \\
0 \\
0 \\
g / l_{0}-(g-\ddot{l}) / l
\end{array}\right] x_{3}
\end{aligned}
$$

ここで, 次の補題を用意する.

[補題] 線形時不変な自由系

$$
\dot{\mathrm{x}}(t)=\mathrm{Ax}(t)
$$


の原点が漸近安定で，基本解が次のように評価できる ものとする.

$$
\left\|\boldsymbol{\phi}\left(t, t_{0}\right)\right\| \leqq K \exp \left[-\alpha\left(t-t_{0}\right)\right], K>1, \alpha>0
$$

このとき, 正定数 $\mu$ が存在し,

$$
\begin{aligned}
& \text { (a) }\|\mathrm{f}(t, \mathrm{x}(t))\| \leqq \mu\|\mathrm{x}(t)\| \\
& \text { (b) } \mu K<\alpha
\end{aligned}
$$

が満たされるなら，摂動系

$$
\dot{\mathrm{x}}(t)=\mathrm{Ax}(t)+f(t, \mathrm{x}(t))
$$

の原点は大域的漸近安定である.

証明）仮定より, 式(22)の解について次の評価が成 立する。

$$
\begin{aligned}
\|\mathrm{x}(t)\| \leqq & K \exp \left[-\alpha\left(t-t_{0}\right)\right]\left\|\mathrm{x}\left(t_{0}\right)\right\| \\
& +\int_{t_{0}}^{t} \mu K \exp [-\alpha(t-\tau)]\|\mathrm{x}(\tau)\| d \tau .
\end{aligned}
$$

それゆえ，次の関係を得る。

$$
\begin{aligned}
& \|\mathrm{x}(t)\| \exp \left[\alpha\left(t-t_{0}\right)\right] \leqq K\left\|_{\mathrm{x}}\left(t_{0}\right)\right\| \\
& \quad+\int_{t_{0}}^{t} \mu K\|\mathrm{x}(\tau)\| \exp \left[\alpha\left(\tau-t_{0}\right)\right] d \tau .
\end{aligned}
$$

ここで，上式に Gronwall の不等式13) を適用すると,

$$
\|\mathrm{x}(t)\| \leqq K\left\|\mathrm{x}\left(t_{0}\right)\right\| \exp \left[(\mu K-\alpha)\left(t-t_{0}\right)\right]
$$

ところが, 仮定の ( b ) より $\mu K-\alpha<0$.

したがって,

$$
\|\mathrm{x}(t)\| \rightarrow 0(t \rightarrow \infty)
$$

が結論される.

さて, 式(21)の時不変線形部分は,

$$
\dot{\mathrm{x}}=\left[\begin{array}{cccc}
0 & 1 & 0 & 0 \\
0 & 0 & 0 & 0 \\
0 & 0 & 0 & 1 \\
0 & 0 & -g / l_{0} & 0
\end{array}\right] \mathrm{x}+\left[\begin{array}{l}
0 \\
1 \\
0 \\
1
\end{array}\right] u
$$

という線形系に次の状態フィードバックを施したもの とみなせる。

$$
u=-\left(k_{\rho T} k_{d T} k_{\rho} k_{d}\right) \mathrm{x}
$$

線形系, 式(23)の可制御性行列を調べるとフルランク になることから, 式(24)の状態フィードバックによっ て任意の位置に固有值を配置することが可能であるこ とが分かる.すなわち式(21)の線形時不変部分の応答 の速さは自由に設計できることが分かる.

次に式(21)の摂動項のノルムを評価してみる.

$$
\begin{aligned}
& \left|\left[g / l_{0}-(g-\ddot{l}) / l\right] x_{3}\right| \\
& \leqq\left(g / l_{0}+|(g-\ddot{l}) / l|\right)\left|x_{3}\right| \\
& \leqq \frac{g}{l_{0}}\left[1+\frac{1+4 a \omega_{0}{ }^{2} / g}{1-a / l_{0}}\right]\left|x_{3}\right| \\
& \leqq \frac{g}{l_{0}}\left[1+\frac{1+4 a \omega_{0}{ }^{2} / g}{1-a / l_{0}}\right]\|\mathrm{x}\| \\
& =\mu\|\mathrm{x}\|
\end{aligned}
$$

ゆえに，補題の内容が適用でき，閉ループ系を漸近安
定化するような状態フィードバック制御が存在する.

以上の結果より, 式(19)の形の制御を採用して定数 ゲインを適切に選ぶと, ロープの長さが周期的に変わ っていても，X軸方向に生じた荷の振れを止め, か つトロリーの位置も同時に制御できることが分かる.

\section{5. 数値実験による検討}

\section{1 理論の検証}

巻き上げ機構を使った $\mathrm{Y}$ 軸方向の荷の振れ止め開 ループ制御に関しては, 式(16)による簡単な開ループ 制御でも振れ止めが期待できるということが示された だけで，振れを完全に止められるかどうかの理論的な 裏付けは得られなかった. 本節では最初に, 数值実験 を通して式(16)の制御がどの程度有効なのかを検討す る.

ロープの長さが $5 \mathrm{~m}$, 荷の上げ下げの振幅を $10 \mathrm{~cm}$ と仮定したときの式(16)による開ループ制御の結果 を，制御を行わないときと比較して Fig. 2 に示す. 制御を行った場合には明らかに制振効果が認められる のが分かるFig. 3 は, 同じロープ長で, 荷を上げ下 げする振幅值を変えた場合の制振結果である，上げ下 げの振幅が大きいほど振動の減衰効果も大きく現れる が, 荷の振れが小さくなった後も制御を続けると逆に 振動を励振するように働いているのが観測される。 こ れは, 荷の振れの振幅值の時間的な変化率が大きくな ったために，付録 B 中の式(B-3)の右辺第二項目が無 視できなくなったためであると解釈される. 以上の数 值実験から明らかなように, 式(16)の開ループ制御方 式は簡単な制御という長所は持つが振れを完全に止め る制御とはなっていないので, 使用に当たっては注意 が必要である，励振を避ける簡便な方法としては，振

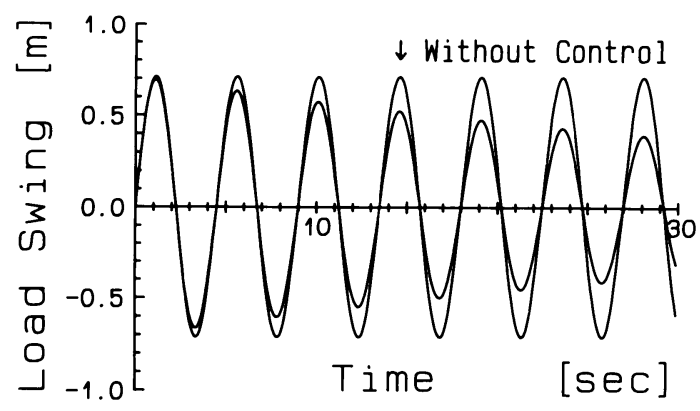

Fig. 2 Load-swing suppression by up-down movement of load initial conditions : $l=5 \mathrm{~m}, \quad i=0.2 \omega_{0} \mathrm{~m} / \mathrm{s}, \ddot{l}$ $=0 \mathrm{~m} / \mathrm{s}^{2}, x=0.1 \mathrm{~m}, \dot{x}=0 \mathrm{~m} / \mathrm{s}, y=0 \mathrm{~m}, \dot{y}=1$ $\mathrm{m} / \mathrm{s}$ 


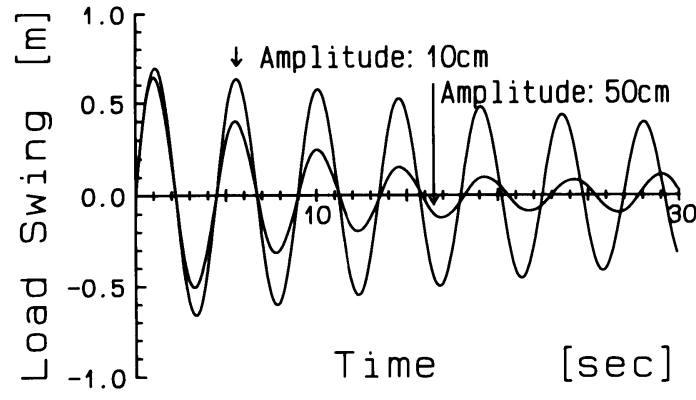

Fig. 3 Load-swing suppression effects by up-down movement of load with various amplitudes

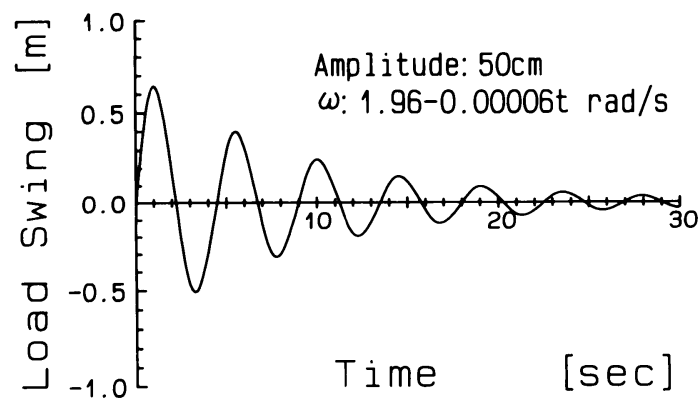

Fig. 4 Load-swing suppression by improved up-down movement of load

動が収まるにつれて荷の上げ下げの周波数を変えてい くのも一つの解決策と思われるので, Fig. 4 にこの改 善策を施した後の実験結果を示す。周波数は一次関数 に従わせて変えた. 周波数のフィードバックは行って いないので，励振現象を生じなくすることは不可能で あるが、Fig. 3 に見られたような早期の励振現象は現 れなくなっている. Fig.5には，トロリーから見おろ したこのときの荷の振動の様子を示す. $\mathrm{Y}$ 軸方向 の振れが減衰するにつれてX 軸の方向の振れが増大 しており荷の上げ下げだけでは楕円を描いて摇れる荷 の振れを止められないという前述の事実が確認でき る.Fig. 6 は Fig. 4 に示した開ループ制御を行いなが ら式(19)に示したトロリーの位置制御とX軸方向の 荷の振れ止め制御を行った結果である.Fig. $6 \mathrm{a}$ に示 したようにトロリーがあらかじめ設定した目標位置で 静止し，かつXY 面内で棈円を描くように振れてい た荷の振動も効果的に抑制されているのが分かる.

なお，以上に示した数值実験では荷の振れに関する 初期条件をすべて同一にしている．数值実験において はロープの張力の時間的な変化も同時にモニタした が、いずれの実験においてもロープが弛むことはなか

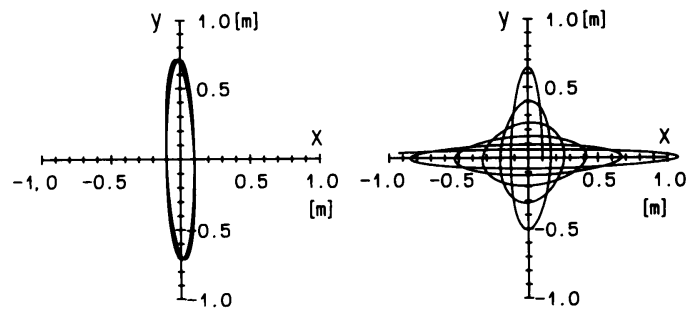

(a) Uncontrolled (b) Controlled

Fig. 5 Load swings projected to XY-plane start point of movement: $(1,0)$ in the planes
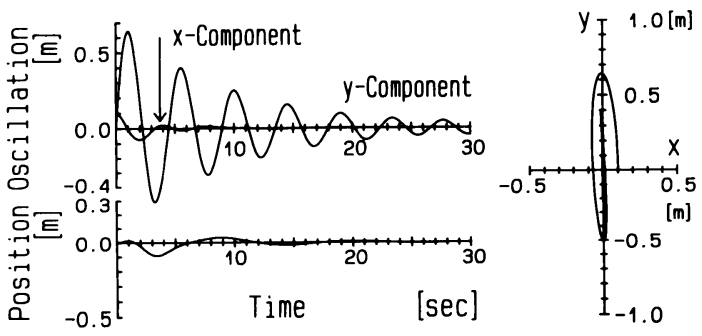

(a) Oscillation components of the load (above) and trolley position (below)

(b) Load-swing projected to XY-plane

Fig. 6 Control performance of proposed controller controller gains : $K_{\rho}=1.0, K_{d}=0.5, K_{\rho T}=$ $-0.5, K_{d T}=-0.5$

つた.

\section{2 より現実的な状況への適用}

これまでの議論では，簡単のためトロリーを駆動す る電動機と巻き上げの電動機に完全な制御系が組まれ ているものと仮定していた，しかし現実には，吊り荷 の運動とトロリーの駆動系や巻き上げ系の運動はそれ ぞれ固有のダイナミクスを持つので, それらが荷の運 動に直接影響を与え, 上述した制御が有効に働くかど うかは疑問となる。 さらに，これまでの議論では，横 方向の荷の摇れを止めるための制御として正弦波関数 に従って荷の上下を行ったが，現実には制御の開始時 点からロープの速度, 加速度までを厳密に正弦波状に 変えることは不可能と考えられるし，また横摇れ抑制 制御を中止してロープの長さを一定にするときの摇れ に及ぼす影響も示されてはいなかった。 そこで本節で はトロリーの駆動系と巻き上げ系のダイナミクスも考 慮に入れた形で数值実験を行い，提案した制御が，よ り現実に近い状況下でも有効かどうかを検討する. 
クレーンの駆動系としては誘導電動機がよく用いら れているが, 近年は誘導電動機でも直流電動機並みの 性能を発揮させることが可能な制御法 ${ }^{14)}$ が提案され ていることもあるので, 簡単のため, トロリーと巻き 上げ機の駆動には直流電動機が使われているものと仮 定する。ただし，現実のクレーンを意識してトロリー 駆動用電動機には速度に関するサーボ制御が，また巻 き上げ機用には位置に関するサーボ制御が施されてい るものとする.

以上に示した点を考慮に入れると, クレーンの吊り 荷の運動は以下のようなダイナミクスに従うことが導 かれる (付録 $\mathrm{C}$ 参照)。

$$
\begin{aligned}
& {\left[M+\frac{J_{1}}{r_{1}{ }^{2}}\right] \ddot{\chi}+m \ddot{x}+\left[\frac{D_{1}}{r_{1}{ }^{2}}+\frac{K_{T 1} K_{V_{1}}}{R_{A 1} r_{1}{ }^{2}}\right] \dot{\chi}} \\
& =\frac{K_{T 1} G_{1}}{R_{A 1} r_{1}} v_{1} \\
& m \ddot{\chi}+m \ddot{x}+\frac{J_{2} x}{r_{2} l} \ddot{l}+\left[\frac{D_{2}}{r_{2}{ }^{2}}+\frac{K_{T 2} K_{V 2}}{R_{A 2} r_{2}{ }^{2}}\right] \frac{x}{l} \dot{l} \\
& =\frac{K_{T 2} G_{2} x}{R_{A 2} r_{2} l} v_{2} \\
& m \ddot{y}+\frac{J_{2} y}{r_{2} l} \ddot{l}+\left[\frac{D_{2}}{r_{2}{ }^{2}}+\frac{K_{T 2} K_{V 2}}{R_{A 2} r_{2}{ }^{2}}\right] \frac{y}{l} \dot{l} \\
& =\frac{K_{T 2} G_{2} y}{R_{A 2} r_{2} l} v_{2} \\
& m \ddot{z}+\frac{J_{2} z}{r_{2} l} \ddot{l}+\left[\frac{D_{2}}{r_{2}^{2}}+\frac{K_{T 2} K_{V 2}}{R_{A 2} r_{2}^{2}}\right] \frac{z}{l} \dot{l} \\
& =\frac{K_{T 2} G_{2} y}{R_{A 2} r_{2} l} v_{2}+m g \\
& x \ddot{x}+y \ddot{y}+z \ddot{z}-l \ddot{l}=-\dot{x}^{2}-\dot{y}^{2}-\dot{z}^{2}+\dot{l}^{2} \\
& \text { ここに } \\
& v_{1}=f_{1}\left[\omega_{r}-\dot{\chi}(t)\right]+f_{2} \int^{t}\left[\omega_{r}-\dot{\chi}(\tau)\right] d \tau-f_{3} \dot{\chi}
\end{aligned}
$$

$\omega_{r}:$ 速度指令值

・巻き上げ機用電動機の入力電圧

$$
v_{2}=g_{1}\left[l_{r}-l(t)\right]+g_{2} \int^{t}\left[\left(l_{r}-l(\tau)\right] d \tau-g_{3} i\right.
$$

\begin{tabular}{|c|c|}
\hline Trolley System & Lifter System \\
\hline $\begin{array}{l}\text { Mass } \\
M: 500 \quad[\mathrm{~kg}] \\
\end{array}$ & $\begin{array}{l}\text { Mass of Load } \\
m: 1000\end{array}$ \\
\hline $\begin{array}{l}\text { Wheel Radius } \\
r: 0.1\end{array}$ & $\begin{array}{l}\text { Drum Radius } \\
r_{2}: 0.2\end{array}$ \\
\hline $\begin{array}{l}\text { Total Inertia } \\
J_{1}: 12.0 \quad\left[\mathrm{kgm}^{2}\right]\end{array}$ & $\begin{array}{l}\text { Total Inertia } \\
J_{2}: 48.0 \quad\left[\mathrm{kgm}^{2}\right]\end{array}$ \\
\hline $\begin{array}{l}\text { Torque Const. } \\
K_{11} \quad 26.1 \quad[\mathrm{Nm} / \mathrm{A}]\end{array}$ & $\begin{array}{l}\text { Torque Const. } \\
\mathrm{K}_{72}: 52.2 \quad[\mathrm{Nm} / \mathrm{A}]\end{array}$ \\
\hline $\begin{array}{l}\text { B. E. M. F. Const. } \\
\dot{K}_{1}: 2.74 \quad[\mathrm{~V} / \mathrm{rpm}]\end{array}$ & $\begin{array}{l}\text { B. E. M. F. Const. } \\
K_{12}: 5.48 \quad[1 \mathrm{rpm}]\end{array}$ \\
\hline $\begin{array}{l}\text { Resistance } \\
R_{1}: 0.4\end{array}$ & $\begin{array}{l}\text { Resistance } \\
R_{2}: 0.4\end{array}$ \\
\hline $\begin{array}{l}\text { Damping Factor } \\
D_{1}: 1700 \quad[\mathrm{Nms} / \mathrm{rad}]\end{array}$ & $\begin{array}{l}\text { Damping Factor } \\
D_{:}: 3000 \quad[\mathrm{Nms} \mathrm{rad}]\end{array}$ \\
\hline $\begin{array}{l}\text { Amp. Gain } \\
G_{1}: 10.0\end{array}$ & $\begin{array}{l}\text { Amp. Gain } \\
(i ; \quad: \quad 10.0\end{array}$ \\
\hline $\begin{array}{l}\text { P. Gain } \\
f_{1} \quad: \quad 200\end{array}$ & $\begin{array}{l}\text { P. Gain } \\
y: \quad 200\end{array}$ \\
\hline $\begin{array}{l}\text { I. Gain } \\
f_{2}: 250\end{array}$ & $\begin{array}{l}\text { I. Gain } \\
y_{:}: \quad 50\end{array}$ \\
\hline $\begin{array}{l}\text { D. Gain } \\
f_{3}: 1\end{array}$ & $\begin{array}{l}\text { D. Gain } \\
y_{+}: 0\end{array}$ \\
\hline
\end{tabular}

$l_{r}:$ 位置指令值

で, Table 1 にそれぞれの記号の意味を示す。また， 数值実験で用いた各パラメータの值も Table 1 に示 す。

Fig. 7 はトロリーの速度制御器と巻き上げ機の位置 制御器をそれぞれ考慮に入れて, Fig. 6 と同様の制御 を行ったときの数值実験結果を示したものである，よ り現実的な状況を模擬するために，制御を開始する時 点でのロープの長さの変化速度と加速度は共に 0 と置
Table 1 Parameters used for simulations

いた、ただし，制御器を含めた巻き上げ機系のダイナ ミクスを考慮に入れて, 制御器に指令值として与える ロープの長さの時間変化には,

$$
l_{r}=5+0.5 \sin \left(2 \omega_{0} t+0.3\right)
$$

のように，位相の補償項を付け加えた。ロープの長さ の変化の周波数は固定したままである。また横摇れ抑 制制御を終了させるときには，ロープの長さが最も長 くなったときに巻き上げ用制御器に $l_{r}=5[\mathrm{~m}]$ の指令 值を与えるようにした.グラフの結果は Fig. 6 のそ れはとほほ一致しており，この場合にも制御が有効に 働くのが分かる. 吊り荷の質量も変えた数值実験も行 つたが，ここで用いたパラメータの場合では，制御結 果にはほとんど差異が見られなかった。なお，トロリ 一駆動用電動機と巻き上げ機用電動機に施した速度サ 一ボ系及び位置サーボ系の各ゲインは試行錯誤的に決 めたものであり，更によい制御性能を示すようなゲイ ンが存在し得る可能性が残されている.

\section{6.おわりに}

地切りの際の横引きや搬送途中の突風などのせいで 生じた吊り荷の横摇れを減衰させ，荷を目標位置まで 搬送する直進形クレーンの制御問題を考えた。 クレー ンの巻き上げ機構を利用すると横摇れは簡単な開ルー プ制御で摇れ減衰させること，また横摇れの振動が 抑えられると吊り荷の鉛直方向の角運動量が保存され るようにトロリーの移動方向の振れが増大してしまう 


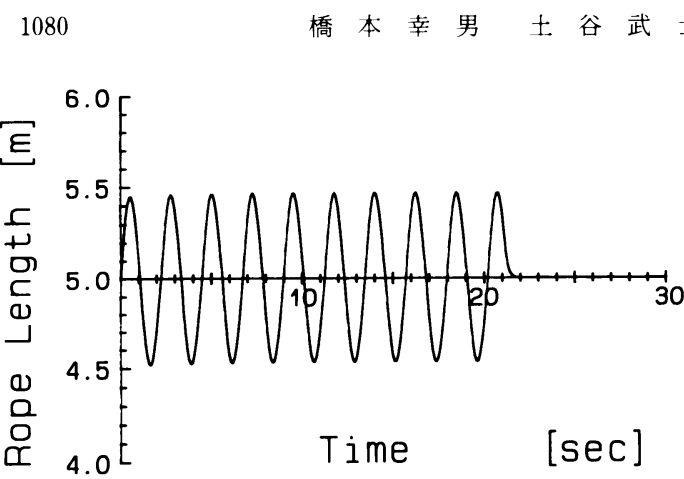

(a) Time variation of rope length

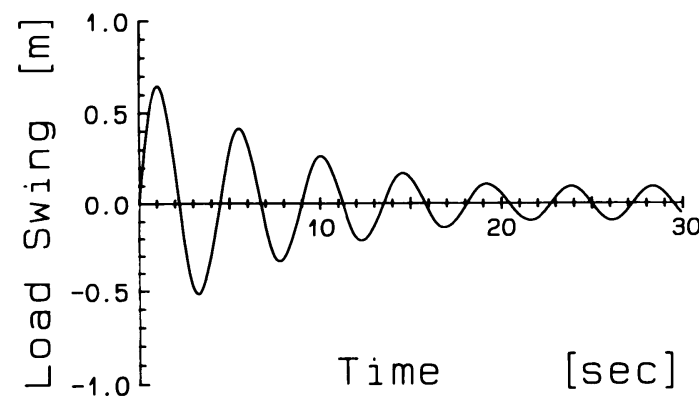

(b) Time variation of transversal load-swing

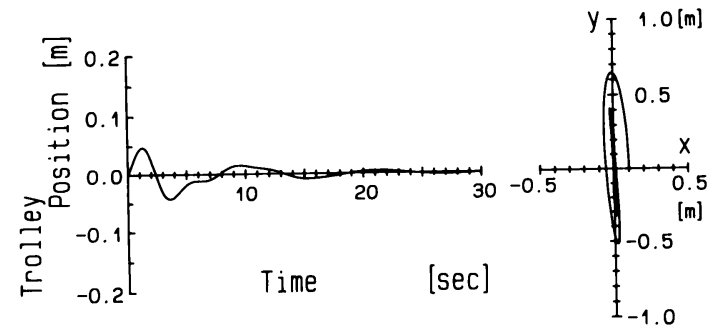

(c) Time variation of trolley (d) Load-swing in position

$\mathrm{X}$-Y plane

Fig. 7 Total control performance of proposed controller

ことを運動方程式の解析から明らかにした．制御にお いては, トロリーの運動は横方向の振動の成分には影 響を与えないという機構上の特徵に着目し，荷の上げ 下げによって楕円を描くように摇れる荷の振動の横方 向成分を減衰させながら大きく振動する方向をトロり 一の移動方向へ回転させ，その振動をトロリーの速度 制御で減衰させつつ荷を目標位置まで搬送する方式を 提案した。この制御の制御性能を数值実験を通して評 価し，トロリーと巻き上げ機のダイナミクスを考慮に 入れた。より現実的なクレーンを想定した場合にも提 案した制御方策が効果的に働くことを数值実験を通し
杉岡一郎松田敏彦

て確認した。

本文で取り扱った横摇れ抑制制御は，ロープの長さ をある長さを中心として正弦波状に変えるという簡単 な方式のため，制御中に荷が不用意に上昇し過ぎた り，降下し過ぎたりという恐れは生じない。 また，正 弦波という滑らかな関数に従ってロープの長さを変え るので, 荷やロープに急激な加速度の変化が加わらな い. しかし反面，横摇れの抑制制御には状態のフィー ドバックを行っていないので，荷の摇れを完全に止め ることはできないし，また外乱にも弱い．数值実験に よれば，ロープの長さを変える周波数を，荷を大きく 上げ下げすることによって生じる横摇れの周波数変化 に合わせるように調節するなら，荷の摇れを 0 にする ことも不可能でないという結果を得ているが, この周 波数もフィードバックするような閉ループ系の構成法 については，現在のところまだ定式化されていない。 今後検討すべき課題と考える.

\section{参 考 文 献}

1）津村, “移動体の知能化”、日本ロボット学会誌, Vol. 10-3, pp. 315-319 (1992)

2）北森, “クレーンの最適運転法”, 第 3 回計測自動制御学会 学術講演会予稿集, pp. 343-348 (1964)

3）美多, 金井, “トロリーの最大速度に注目したクレーンの最 適運転法”, 計測自動制御学会論文集, Vol. 15-6, pp. 833838 (1979)

4）進藤他, “コンテナ・クレーンの振れ止め制御”, 計測自動制 御学会論文集, Vol. 19-5, pp. 430-432（1983）

5）大平, 久村, “可変ロープ長振子の振動制御”, 計測自動制御 学会論文集, Vol. 19-9, pp. 759-761（1983）

6）森下, “走行クレーン運転自動化のための振れ止め制御”, 計測自動制御学会論文集, Vol. 14-6, pp. 739-744 (1978)

7）田村他, “適応同定機構を有する巻上げ式天井クレーンの 制御”, 日本機械学会論文集 (C 編)，Vol. 54-504, pp. 17951803 (1988)

8）相良，大川、“クレーンの適応制御”，日本機械学会論文集 (C 編)，Vol. 56-526, pp. 1494-1498 (1990)

9）橋本他, “振饥角情報を必要としない走行クレーンの振れ 止め・位置制御”, 第 23 回計測自動制御学会北海道支部学 術講演会論文集, pp. 25-26 (1991)

10） L.E. Elsgolc (瀬川訳), “科学者・技術者のための変分法” IV章, pp. 119-139 ブレイン図書出版（1972）

11）太田他, “分布定数系モデルを利用した旋回型クレーンの 振動制御”、第 7 回日本ロボット学会学術講演会予稿集, pp. 405-406 (1989)

12）江沢他, “演習詳解力学”, p. 30, 東京図書 (1989)

13）山本, “常微分方程式の安定性”, pp. 30-31, 実教出版 (1983)

14）中野, 橋井, “交流電動機のベクトル制御, コンピュートロ ール”, 4, pp. 44-51, コロナ社（1983）

\section{付録 A. クレーンの運動方程式の導出}

式 $(5$ )の第一変分をとって, 


$$
\begin{aligned}
\delta J= & \int_{t_{1}}^{t_{2}}\left[\delta L+\left(x^{2}+y^{2}+z^{2}-l^{2}\right) \delta \lambda\right. \\
& +2 \lambda(x \delta x+y \delta y+z \delta z)] d t
\end{aligned}
$$

を得る。ここで,

$$
\begin{gathered}
\delta L=\frac{\partial L}{\partial \dot{x}} \delta \dot{x}+\frac{\partial L}{\partial \dot{y}} \delta \dot{y}+\frac{\partial L}{\partial \dot{z}} \delta \dot{z}+\frac{\partial L}{\partial z} \delta z \\
\delta x\left(t_{1}\right)=\delta x\left(t_{2}\right)=0 \\
\delta y\left(t_{1}\right)=\delta y\left(t_{2}\right)=0 \\
\delta z\left(t_{1}\right)=\delta z\left(t_{2}\right)=0
\end{gathered}
$$

であることに注意して式(A-1)の部分積分を実行する と,

$$
\begin{aligned}
\delta J= & \int_{t_{1}}^{t_{2}}\left\{\left[-\frac{d}{d t}\left[\frac{\partial L}{\partial \dot{x}}\right]+2 \lambda x\right] \delta x+\left[-\frac{d}{d t}\left[\frac{\partial L}{\partial \dot{y}}\right]\right.\right. \\
& +2 \lambda y] \delta y+\left[-\frac{d}{d t}\left[\frac{\partial L}{\partial \dot{z}}\right]+\frac{\partial L}{\partial z}+2 \lambda z\right] \delta z \\
& \left.+\left(x^{2}-y^{2}+z^{2}-l^{2}\right) \delta \lambda\right\} d t
\end{aligned}
$$

それゆえ, 変分学における基本定理から，第一成分を 0 とする条件は以下のように求まる.

$$
\begin{gathered}
-\frac{d}{d t}\left[\frac{\partial L}{\partial \dot{x}}\right]+2 \lambda x=0 \\
-\frac{d}{d t}\left[\frac{\partial L}{\partial \dot{y}}\right]+2 \lambda y=0 \\
-\frac{d}{d t}\left[\frac{\partial L}{\partial \dot{z}}\right]+\frac{\partial L}{\partial z}+2 \lambda z=0 \\
x^{2}+y^{2}+z^{2}-l^{2}=0
\end{gathered}
$$

ここで，式(1)を式(A-2)，(A-3)，(A-4)に代入す ることにより,

$$
\begin{gathered}
m(\ddot{x}+\ddot{x})=2 \lambda x \\
m \ddot{y}=2 \lambda y \\
m \ddot{z}=m g+2 \lambda z
\end{gathered}
$$

の関係が得られる。一方, 式 $(A-5)$ を時間に関して 2 回微分することにより，

$$
\dot{x}^{2}+x \ddot{x}+\dot{y}^{2}+y \ddot{y}+\dot{z}^{2}+z \ddot{z}-\dot{l}^{2}-l \ddot{l}=0
$$

これが式(A-6)，(A-7)，(A-8) 中のラグランジュの 末定関数を決める関係式になる。実際式(A-6), (A7)，(A-8)を式(A-9)に代入すると，ラグランジュの 末定関数は次のように定まる.

$\lambda=-\frac{m}{2 l^{2}}\left(\dot{x}^{2}+\dot{y}^{2}+\dot{z}^{2}+z g-\dot{l}^{2}-l \ddot{l}-x \ddot{x}\right)(\mathrm{A}-10)$

式(A-10)を式(A-6)，(A-7)，(A-8)に代入・整理す ると運動方程式が求められ, 本文中の式 $(6) \sim(8)$ を 得る。

\section{付録 B. 式(18)の導出}

式(17)式の時間微分をとって,

$$
\dot{E}=\dot{y} \ddot{y}+\frac{g}{l_{0}} y \dot{y}
$$

ここで，式(14)を上式に代入すると次式を得る.

$$
\dot{E}=y \dot{y}\left(-\frac{g-\ddot{l}}{l}+\frac{g}{l_{0}}\right)
$$

式(15)，（16)を代入して計算を進めると式(B-2)は以 下のように変形できる.

$$
\begin{aligned}
\dot{E}= & {\left[A_{y}{ }^{2} \omega_{0} \sin \left(\omega_{0} t\right) \cos \left(\omega_{0} t\right)\right.} \\
& \left.+A_{y} \dot{A}_{y} \sin ^{2}\left(\omega_{0} t\right)\right] \\
& \times\left(-\frac{g+4 a \omega_{0}{ }^{2} \sin \left(2 \omega_{0} t\right)}{l_{0}+a \sin \left(2 \omega_{0} t\right)}+\frac{g}{l_{0}}\right) \\
= & {\left[A_{y}{ }^{2} \omega_{0}{ }^{3} \sin \left(\omega_{0} t\right) \cos \left(\omega_{0} t\right)\right.} \\
& \left.+A_{y} \dot{A}_{y} \omega_{0}{ }^{2} \sin ^{2}\left(\omega_{0} t\right)\right] \\
& \times\left(-\frac{1+4 a \omega_{0}{ }^{2} \sin \left(2 \omega_{0} t\right) / g}{1+a \sin \left(2 \omega_{0} t\right) / l_{0}}+1\right) \\
= & {\left[A_{y}{ }^{2} \omega_{0}{ }^{3} \sin \left(\omega_{0} t\right) \cos \left(\omega_{0} t\right)\right.} \\
& \left.+A_{y} \dot{A}_{y} \omega_{0}{ }^{2} \sin { }^{2}\left(\omega_{0} t\right)\right] \\
& \times \frac{-4 a \omega_{0}{ }^{2} \sin \left(2 \omega_{0} t\right) / g+a \sin \left(2 \omega_{0} t\right) / l_{0}}{1+a \sin \left(2 \omega_{0} t\right) / l_{0}} \\
= & {\left[\frac{a A_{y}{ }^{2} \omega_{0}{ }^{3} \sin ^{2}\left(2 \omega_{0} t\right)}{2}\right.} \\
& \left.+a A_{y} \dot{A}_{y} \omega_{0}{ }^{2} \sin ^{2}\left(\omega_{0} t\right) \sin \left(2 \omega_{0} t\right)\right] \\
& \times \frac{-4 \omega_{0}{ }^{2} / g+1 / l_{0}}{1+a \sin ^{2}\left(2 \omega_{0} t\right) / l_{0}} \\
= & -\frac{3 a A_{y}{ }^{2} \omega_{0}{ }^{3} \sin ^{2}\left(2 \omega_{0} t\right)}{2\left[l_{0}+a \sin ^{2}\left(2 \omega_{0} t\right)\right]} \\
& -\frac{3 a A_{y} \omega_{0}{ }^{2} \sin ^{2}\left(\omega_{0} t\right)}{l_{0}+a \sin \left(2 \omega_{0} t\right)} \dot{A}_{y} \sin \left(2 \omega_{0} t\right)
\end{aligned}
$$

ここで，荷の上げ下げの振幅をごく小さく選ぶものと すれば，振れに及ぼす影響も小さくなると考えられる から振れの振幅変化は,

$$
\dot{A}_{y} \fallingdotseq 0
$$

とみなせる.したがって,このときには式(B-3) は次 式で近似できる.

$$
\dot{E}=-\frac{3 a A_{y}{ }^{2} \omega_{0}{ }^{3} \sin ^{2}\left(2 \omega_{0} t\right)}{2\left[l_{0}+a \sin \left(2 \omega_{0} t\right)\right]}
$$

上式の分母は仮定より，

$$
0<l-a \leqq l_{0}+a \sin \left(2 \omega_{0} t\right)
$$

となり常に正の值をとるので本文中の式(18)の主張が 成り立つ。

\section{付録 $\mathrm{C}$. 駆動系を考慮したクレーンの状態方程式}

通常は電動機の電気的時定数は機械系の時定数より も小さいと考えてもよいから，ここでも電気系のダイ ナミクスを省略した以下の式をトロリーと巻き上げ機 をそれぞれ駆動する直流電動機の運動方程式と考え る.

$$
J_{1} \ddot{\theta}_{1}+\left(D_{1}+\frac{K_{T 1} K_{v_{1}}}{R_{1}}\right) \dot{\theta}_{1}+f_{T} r_{1}=\frac{K_{T 1} G_{1}}{R_{1}} v_{1}
$$




$$
J_{2} \ddot{\theta}_{2}+\left(D_{2}+\frac{K_{T 2} K_{V 2}}{R_{2}}\right) \dot{\theta}_{2}-f_{L} r_{2}=\frac{K_{T 2} G_{2}}{R_{2}} v_{2}
$$

ただし，

$\theta_{1}:$ トロリ一駆動用電動機の回転角度

$f_{T}:$ トロリーの駆動に消費される力

$\theta_{2}:$ 巻き上げ用電動機の回転角度

$f_{L}:$ ロープの張力

をそれぞれ表す。ここで，トロリーがレール上を滑る ことなく移動できるものとすれば,

$$
\dot{\chi}=r_{2} \dot{\theta}_{1}
$$

このことから, 式(C-1)はトロリーの位置に関する式 に書き直すことができて，

$$
\begin{aligned}
& \frac{J_{1}}{r_{1}{ }^{2}} \ddot{\chi}+\left[\frac{D_{1}}{r_{1}{ }^{2}}+\frac{K_{T_{1}} K_{V_{1}}}{R_{1} r_{1}{ }^{2}}\right] \dot{\chi}+f_{T} \\
& \quad=\frac{K_{T 1} G_{1}}{R_{1} r_{1}} v_{1}
\end{aligned}
$$

を得る、ロープが弛まないという条件を仮定すると， 巻き上げ用電動機についても同様に,

$$
\begin{aligned}
& \frac{J_{2}}{r_{2}^{2}} \ddot{l}+\left[\frac{D_{2}}{r_{2}^{2}}+\frac{K_{T 2} K_{V 2}}{R_{A 2} r_{2}{ }^{2}}\right] j-f_{L} \\
& =\frac{K_{T 2} G_{2}}{R_{A 2} r_{2}} v_{2}
\end{aligned}
$$

を得る.

次に, 荷の摇れを記述する運動方程式を明らかにす る。付録 A で取り扱った場合と異なり,この場合に はトロリーの運動も同時に考える必要があるので, 系
のラグランジュアンは以下のように計算し直さなけれ ばならない.

$$
L=\frac{1}{2} M \dot{\chi}^{2}+\frac{1}{2} m\left[(\dot{x}+\dot{\chi})^{2}+\dot{y}^{2}+\dot{z}^{2}\right]+m g z
$$

また，トロリーを駆動する力とロープの張力がこの系 に対して外力として作用していることも付録 A の場 合と異なっている．これらの外力のせいで系になされ る仮想仕事は，

$$
\delta W=f_{T} \delta \chi+f_{L} \delta l
$$

となる．

さて, 式(C-5), (C-6)を使い, 拘束条件

$$
x^{2}+y^{2}+x^{2}=l^{2}
$$

を考慮に入れてハミルトンの原理を適用すると, 以下 の関係式を得る。

$$
\begin{gathered}
M \ddot{\chi}+m \ddot{x}=f_{T} \\
m \ddot{\chi}+m \ddot{x}=-\frac{x}{l} f_{L} \\
m \ddot{y}=-\frac{y}{l} f_{L} \\
m \ddot{z}=-\frac{z}{l} f_{L}+m g \\
x^{2}+y^{2}+x^{2}=l^{2}
\end{gathered}
$$

ここで, 式(C-3) と式(C-4)からトロリーの駆動力と ロープの張力をそれぞれ求めて, 式(C-7) から式(C10)に代入・整理すると，本文に示した式(25)〜(28)を 得る。なお, 式(29) は式(C-11)を時間で 2 回微分し て導出した関係式である。

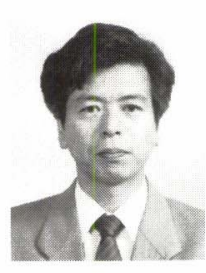

\section{橋本幸男}

(Yukio HASHIMOTO)

1953 年 3 月 8 日生. 1979 年室蘭工業大学 大学院修士課程電子工学専攻修了. 高校の非 常勤講師等を経て 83 年室蘭工業大学電子工 学科助手. 90 年上り同大学電気電子工学科助 手. 制御工学, メカトロニクスの研究に従事, 計測自動制御学会の会員. (日本ロボット学会正会員)

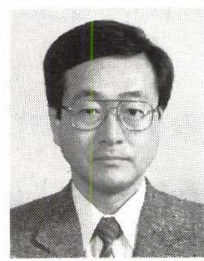

\section{杉岡一郎 (Ichiro SUGIOKA)}

1941 年 8 月 30 日生. 1965 年室蘭工業大学 電気工学科卒業. 70 年北海道大学大学院修士 課程電気工学専攻修了. 71 年室蘭工業大学電 子工学科助手. 85 年助教授. 93 年同大学情報 工学科教授.工学博士. 主としてコンピュータ の教育利用に関する研究に従事. 情報処理学 会電子情報処理学会, CAI 学会の会員.

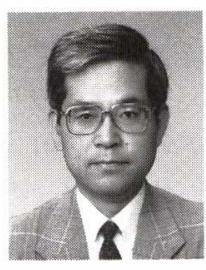

\section{土谷武士}

\section{(Takeshi TSUCHIYA)}

1941 年 2 月 7 日生. 1965 年北海道大学大 学院修士課程電気工学専攻修了. 北海道大学 工学部電気工学科講師, 助教授を経て現在教 授. 制御工学, ロボット工学, パワーエレクト ロニクスなどの研究に従事. 工学博士. 計測 自動制御学会, システム制御情報学会, 日本機械学会, 日本ファジ 亿学会, IEEEの会員.

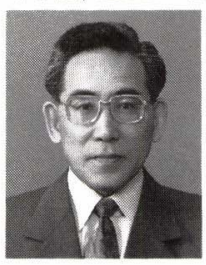

\section{松田敏彦}

(日本ロボット学会正会員)

\section{(Toshihiko MATSUDA)}

1934 年 1 月 20 日生. 1956 年室蘭工業大学 電気工学科卒業. 北海道大学工学部助手, 室 蘭工業大学講師, 助教授を経て, 78 年教授. 工 学博士. 現在室蘭工業大学情報処理教育セン ター長. 電気機器, 電動機の抑制の研究に従 事. 電気学会, 炭素材料学会の会員. (日本ロボット学会正会員) 